\title{
HVEM PLYNDRER STATEN?
}

\author{
Mogens Holm og Arne Kurdahl:
}

\section{Indledning}

Allan Andreassens og Tyge Kjærs (AT) artikel i Kurasje nr. 25 »Arbejderklassens situation og den statslige krisepolitik « bidrager til videreførelse af den omfattende stats- og reproduktionsdiskussion, der har fundet sted i Kurasje, i antologien »Socialpolitik og kapitalisme« og i »Arbejderens situation, de sociale problemer og revolutionen . $^{1}$

Artiklens bidrag til diskussionen beror på en påvisning af, »at det centrale indhold i den statslige krisepolitik - for ikke at sige det eneste strukturerende indhold - er fors $ø \mathrm{~g}$ på at påvirke udbytningsforholdene og udbytningsresultatets fordeling mellem stat og kapital.« (s. 125).

Det er artiklens intention gennem en kortlægning af udviklingen i udbytningsrelationen og profitfondens fordeling mellem stat og kapital at bidrage til et billede af krisepolitikkens konsekvenser for arbejderklassens situation.

Præciseringen af, at udviklingen i udbytningsrelationen er det præformerende forhold for alle udviklingsformer i det borgerlige samfund, angiver artiklens placering i politik/økonomi-diskussionen og peger samtidig på den historiske kontekst, hvor dette forhold ikke kun er præformerende i teoriens verden, men hvor kapitalen træder frem som det, den er: samfundets subjekt.

Jo længere den nuværende krise varer, jo længere et egentlig opsving udebliver, jo større bliver presset på den stat, der primært eksisterer i sine omfordelinger, for at bevæge den til at omfordele den samfundsmæssige konsumkraft fra arbejde til kapital, fra uproduktivt konsum til produktivt. Lykkes denne politik, eller lykkes den ikke, dette spørgsmål har nok så megen praktisk interesse, men

1. Især i Kurasje 23/24, Viborg 1980, i antologien Socialpolitik og kapitalisme, forlaget Kurasje Kbh. 1978 og i Finn Dam Rasmussen, Arbejderens situation, de sociale problemer og revolutionen, forlaget Kurasje Kbh. 78. 
bærer samtidig stof i sig i form af konkretiseringer, af historiske iklædninger til den teoretiske diskussion af arbejderklassens situation i krisen. Diskussionen heraf er langt fra ny, den er så gammel som arbejderklassen selv, men får sit opsving i faser, hvor kapitalismen ikke »indenfor produktionen « er i stand til at gennemføre de ændringer i arbejderklassens situation, der er og bliver forudsætningen for den kapitalistiske ekspansion.

Sænkningen af arbejdskraftens værdi er den væsentligste forudsætning for genopsving i den kapitalistiske akkumulation. I de faser, hvor kapitalen ikke i tilstrækkelig grad er i stand til selv at frembringe denne sænkning, retter opmærksomheden sig imod de fors $\emptyset$ g, der fra omfordelingsstatens side gøres på at bidrage til denne »sænkning af værdien«. Dette kommer i DK især til udtryk i forsøgene fra de borgerlige partiers side på at presse beskæringer igennem overfor foranstaltninger, der ikke i borgerlig $\varnothing$ konomisk forstand er »produktive«, de dele af den statslige politik, der uproduktivt beslaglægger dele af nationalindkomsten. Jo længere jo mere bliver dette nedskæringsimperativ også en realitet for det socialdemokrati, der mere end noget andet parti har stået som formidleren af de reproduktive elementer, der ikke har kunnet sikres via lønformen. ${ }^{2}$ I den udstrækning, der bliver tale om realiseret politik, bliver inddragelsen af disse foranstaltninger i en diskussion af arbejderklassens situation et uomgængeligt element for så vidt denne diskussion skal bidrage til at gennemlyse de materielle, bevidsthedsmæssige og politiske træk, der afsættes i arbejderklassen i denne krise. En analyse af den statslige krisepolitik, der retter sig mod reproduktionsvilkårene, direkte eller indirekte, således som det er tilfældet med AT's artikel i sidste nummer af Kurasje, er derfor vigtig.

Som det tydeligt fremgår af den diskussion, der har været ført i tidsskriftet gennem længere tid, er der langt fra opnået en klarhed om betydningsindholdet af en lang række af de teoretiske begreber, der danner fundamentet i denne analyse, ligesom det ikke er entydigt, hvilke aspekter af og hvordan de empiriske realiteter skal medtages. ${ }^{3}$ For ikke at falde tilbage til en lukning af denne diskussion, fordres der kritisk opmærksomhed overfor tidligere bidrag og forsigtighed med den betydning og den rækkevidde man tildeler sine teoretiske begreber og sine historiske og empiriske kategoriseringer.

2. Bidrag til denne diskussion findes i artiklerne af Brinch, Bredsdorff og Hansen, Indkomstpolitik og kapitalakkumulation i Danmark, Kurasje nr. 17 og Arbejderklassen og kapitalismen - om reformismens udviklingsbetingelser, Kurasje nr. 21.

3. Sammenlign f.eks. Finn Hansson og Peder Lærke Nielsen, Statsintervention og reformismekritik, Kurasje 23/24, 1980, og den såkaldte realanalysediskussion der kan stiftes bekendtskab med bl.a. hos Chr. Toft i Kurasje 25, 1980 og Kurt Aagaard Nielsen, Til diskussion af det metodiske grundlag for historisk analyse/kritik af akkumulationsprocessen, Nordisk Forum nr. 16. 
Grundlaget for artiklens konklusioner peger i vore øjne umiddelbart på problemet om, hvorvidt man rimeligt omfattende kan bestemme arbejderklassens situation gennem de empiriske mål og teoretiske begreber om udbytningsrate og profitfordeling, der opereres med.

Det handler vores kommentar i hovedsagen om, og vi skal som udgangspunkt i forhold hertil pege på hvilke aspekter begrebet »arbejderklassens situation « også indeholder. Ned gennem kommentaren vil vi søge at fastholde, at interessen må gå i retning af en åbning af denne diskussion, og vi vil pege på hvilke punkter, der i diskussionerne efter vores mening er utilstrækkeligt bearbejdede.

\section{Arbejderklassens situation}

Begrebet arbejderklassens situation er dobbelttydigt på flere niveauer:

Arbejderindividets eksistens er delt op i to områder, i produktionen og i reproduktionen. Når denne opdeling er blevet påpeget mange gange tidligere og understreget i reproduktionsniveau og -kampdiskussionerne skyldes det opdelingens afgørende karakterisering af det særegne ved lønarbejderens eksistensform: På den ene side er eksistensen som arbejder direkte underlagt kapitalens kommando i produktionen. På den anden side afhænger deres eksistens af individernes muligheder for at genskabe arbejdsevnen i en afsættelig form, dvs. afhænger af muligheden for at organisere reproduktionen således, at arbejdskraften kan indgå i produktions- og udbytningsprocessen.

I selve reproduktionsprocessen kan modsætningerne i arbejderklassens situation tematiseres udfra flere problemstillinger:

1. Processen er frigjort fra produktionen - ligger udenfor kapitalens kommando - men er i hele sin form præformeret af lønafhængigheden.

I reproduktionen står arbejderne frit - men frit på den måde at »friheden « er indhegnet af arbejdskraftens salgsbetingelser og -muligheder og på den måde, at det borgerlige samfunds frihedsform overhovedet kun kan udnyttes for så vidt arbejdskraften kan sælges. Friheden indsnævres radikalt, hvis muligheden for at realisere arbejdskraftsreproduktionen likvideres og afløses af offentlig forsørgelse.

2. I den familiale eller helt individuelle eksistens står arbejderne som autonomiserede individer, men er samtidig som klasse underlagt de offentlige interventioner og kontrolforanstaltninger.

Hvor forskellen egentlig ligger imellem den selvstændigt organiserede reproduktion og klassespecifikke intervention/kontrol fra det offentlige, kan vi 
kun tematisere ud fra modsætningsforhold i arbejderklassens situation. Lidt for overordnet kan problemet antydes ud fra modsætningen imellem arbejderindividernes reproduktionsbehov og den tendentielle samfundsmæssige ensliggørelse af reproduktionsniveau og -muligheder. En ensliggørelse der realiseres gennem lønformen og reproduktionskampen. De offentlige interventioners samfundsmæssige funktion beror netop på indgreb overfor dette modsætningsforhold således, at reproduktionsmulighederne gennemsnitliggøres for de arbejdsmarkedstilknyttede. For de dele af arbejdsstyrken, der ikke (mere) har nogen funktion i forhold til arbejdsmarkedet eller i forhold til reservearmeen, umuliggøres reproduktionen som arbejdskraft.

Kapitalens herredømmeforhold udenfor kommandoen i produktionsprocessen udøves således af staten overfor arbejderklassen og får konsekvenser for arbejderklassens livssituation og reproduktionskamp ved dels at kompensere for forskelligheder i reproduktionsbehov og dels ved at fjerne reproduktionsmulighederne. Fsv staten faktisk har indflydelse på arbejdskraftens variabilitet medfører interventionerne ændringer i arbejdernes konkurrencebetingelser på arbejdsmarkedet, på arbejderklassens styrke i reproduktionskampen og dermed på lønningernes bevægelse omkring værdien.

3. Som det sidste element i modsætningerne i reproduktionen vil vi pege på modsætningen mellem tilpasning og frigørelse, som de kapitalistiske reproduktionsformer afsætter som en erfaring hos arbejderne, en erfaring som virker ind på den praksis som arbejderklassen organiserer sin livssituation igennem. Således står både kapital og stat overfor arbejderklassen som de institutionelle rammer for arbejdereksistensen, men som samtidig indeholder risiko/muligheder for eksistensens sammenbrud. I kampen for ændringer i livssituationen står stat og kapital således både som faktor i arbejderinteressens realisering og som likvidator af reproduktionsinteresserne.

Med denne udspænding af begrebet arbejderklassens situation har det været vores mening dels at pege på hvilke aspekter vi anser for nødvendige at tage ind i en samlet diskussion af de økonomiske, sociale og politiske konsekvenser af ændringerne i arbejderklassens situation, dels at præcisere den kontekst vi diskuterer ATs artikel i.

Artiklens grundlag for at diskutere krisepolitikkens effekter på arbejderklassens situation går i to retninger:

1. Reproduktionsomkostningerne for de beskæftigede og de ubeskæftigede.

2. Totalprofittens størrelse.

Artiklen åbner således op for en diskussion dels af effekterne af de førte krisepolitikker, dels af rationaliteten heri; effekter og rationalitet i forhold til på den ene side arbejderklassens levevilkår og på den anden side spørgsmålet om 
profitmassens fordeling mellem stat og kapital og om forøgelsen af den totale profitmasse. Resultaterne af analysen viser, at indgrebene hverken kan siges at være særligt effektive eller særligt rationelle mht. at bidrage til kriseløsningen. Det skal vi vende tilbage til.

Artiklen vender efter vores mening tilbage til en »løn- $\varnothing$ konomisk « helhedsbestemmelse af de materielle reproduktionsbetingelser. Den udløser med sit udgangspunkt i industristatistikkens lønopgørelser og budgetredegørelser flere og andre spørgsmål end den sædvanlige realanalysediskussion. F.eks. andre spørgsmål end om det er muligt på basis alene af disse fordelingsrelationer at bestemme »statens materielle grundlag « og »fastlægge den statslige krisepolitiks historisk specifikke begreb (s. 125).

Vi vil i følgende skitsere nogle af de hovedproblemer, som vi mener artiklen rejser, men ikke løser:

\section{Hvilken sammenhæng er der mellem udbytningsgrad og reprodukti- onsomkostninger og -vilkår?}

I diskussionen om arbejderklassens situation og reproduktionsvilkår har fokuseringen på eller inddragelsen af udbytningsraten kun perspektiver i den udstrækning, den kan sættes i sammenhæng med reproduktionsbetingelserne. Hvad betyder en forøgelse af udbytningsraten for arbejderklassen, hvis den ledsages af en massiv forbedring af deres materielle og immaterielle levevilkår? Hvad betyder sænkningen af udbytningsraten - som i krisen (iflg. artiklens tabel 2 og 8) hvis den ledsages af beskæringer i reproduktionen? Alene en henvisning til at udbytningen er forøget er i denne sammenhæng ikke tilstrækkeligt. Ganske vist er det klart, at den produktivkraftsudvikling, der har været bærende for kapitalismens ekspansion i slutningen af den lange prosperitet, primært har haft sin rationalitet $\mathrm{i}$ en sænkning af reproduktionsomkostninger for den produktive kapitals elementer, men sideløbende hermed er det tydeligvis lykkedes lønarbejderne at fastholde og i ringere grad forøge den disponible realløn. Hertil kommer at en tiltagende del af reproduktionen formidles gennem statslige foranstaltninger.

Det normale er vel at reproduktionsomkostningerne - forstået som den mængde arbejde, der skal anvendes til reproduktion af arbejdskraften - aftager med stigende udbytningsrate. Sagt på en anden måde, at stigningen i udbytningsraten frembringes via stigning i produktiviteten, resulterende $i$ et fald $i$ anvendelsen af levende arbejde til at producere reproduktionsgoder. Alene en stigning i konsummiddelsektorens produktivitet vil derfor have effekten at sænke reproduktionsomkostningerne uden en ændring i kapitalsammensætningerne (den organiske) indenfor produktionsmiddelsektoren, eller rettere: uden at ændre kapitalstrukturen (produktionsprocessen). 
Alene at slutte fra ændringer i det mål for udbytningsraten og arbejdsdagens deling mellem kapital, stat og arbejde som anvendes i artiklen, til reproduktionssituation er derfor langt fra uden problemer. Spørgsmålet forbliver vel, hvad der overhovedet indgår i reproduktionsomkostningerne og på hvilket niveau det kan og skal diskuteres.

Det er vigtigt på den ene side at fastholde en skelnen imellem den del af arbejdsdagen, der tilfalder kapitalen, og den del, der tilfalder arbejderne, som udgangspunkt for diskussionen af udviklingsretningen i arbejdskraftens værdi, men på den anden side ikke at bilde sig selv eller andre ind, at dette delingsforhold siger alt, hvad der er at sige om udviklingen i arbejdskraftens værdi, udviklingen i reproduktionsomkostningerne og -vilkårene, eller hvad man vil.

\section{Hvorledes skal den del af reproduktionen, der formidles via staten, placeres ind i forhold til bestemmelsen af arbejdskraftens værdi, hhv. merværdien}

Gennem de offentlige ydelser kan stat, kommune og amt indvirke på reproduktionsomkostningerne og profitmassens fordeling. Men for at få et glimt af hvordan de offentlige udgifter ser ud i forhold til kapital/ profit og lønarbejde/reproduktion må opmærksomheden dreje sig i retning af indholdet, karakteren og effekterne af de offentlige ydelser på arbejdsmarkedet og i industripolitikken.

Statens interventionsmuligheder hænger naturligvis sammen med disse interventioners finansieringsmuligheder - klart - men det bliver meningsløst alene at betragte statsinterventionerne ud fra de tilrådighed stående revenuegrundlag, og overse de samfundsmæssige reproduktionsproblemer og -indhold, der nødvendigg $\varnothing r$ offentlige interventioner. Det forbliver meningsløst alene at forklare interventionerne ud fra finansieringsgrundlaget. Det man går glip af er ikke alene nødvendigheden af et bestemt stofligt indhold, men også den modsætning der resulterer af at en reproduktionsforanstaltning af bestemt karakter, er blevet en forudsætning for reproduktionen, mens dens demontering er blevet en forudsætning for akkumulationen. Altså en variation af den gammelkendte modsætning mellem stof og værdi.

ATs argumentationskæde kommer klarest frem når de skriver at »Under akkumulationsbetingelser hvor udbytningsraten vokser - dvs. under den »intensive« kapitalakkumulation, vil statsapparatet have største muligheder for at $\emptyset$ ge beskatningen uden at den bringer sig i modsætningsforhold til kapitalen.«(s.90).

Der er flere problemer i denne formulering:

Kapitalens ulvehunger efter profit er umættelig og profitmassens størrelse kan i sig selv aldrig være tilstrækkelig baggrund for et forøget offentligt forbrug. 
Men især under intensiv kapitalakkumulation må kapitalen kollidere med sine egne forudsætninger. Intensiveringen er tendentielt forbundet med nedgang i den anvendte mængde arbejde og dermed fald i profitraten. Om end profitmassen stiger, er problemet, at den ikke stiger nok og det netop i en fase, hvor intensiveringen af arbejdet, ændringer i arbejdsprocessen og udskiftninger af arbejdere nødvendigg $\varnothing \mathrm{r} \emptyset$ gede statslige udgifter til arbejdskraftsreproduktionen.

Det er altså ikke et ydre modsætningsforhold (eller mangel på samme) mellem stat og kapital der er problemet, men et modsætningsforhold der ligger i kapitalen selv og kommer til udtryk i statens måde at udøve kapitalens produktionseksterne herredømmeforhold på. ${ }^{4}$ En omfattende fremstilling af statens funktion er lejligheden ikke til ${ }^{5}$, men en kort reference til kapitalmodsætningerne som statens konstitutionsgrundlag - statens omfattende indflydelse på kapitalernes og arbejdernes konkurrenceforhold - gør, at en henvisning til at statens udgiftsposter fordeler sig med $60 \%$ på almene produktionsbetingelser og $40 \%$ på reproduktionen og sociale udgifter, bliver en udækkende bestemmelse (artiklens s. 97).

ATs empiriske materiale - kun omfattende industristatistikken, dvs. 1øn og beskæftigelse indenfor industrien, og opgørelser af de offentlige udgifter på visse hovedposter - beskriver udviklingen i industriarbejdernes lønninger (når skatten er trukket fra får AT et udtryk for den disponible realløn, som stort set ikke ændrer sig i den unders $\emptyset$ gte periode) arbejdsdagens fordeling mellem stat, kapital og arbejde, og endelig en fordeling af statens udgifter.

På den måde søger AT en forklaring på krisepolitikkens konsekvenser for arbejderklassen i nogle yderst - statistisk set - begrænsede opgørelser over pris/ værdi bevægelser og udbytningsratens bevægelser.

Dermed overses hele pointen og det særlige ved arbejderklassens situation og ved køb og salg af arbejdskraft, nemlig at bæreren af varen arbejdskraft, arbejderindividet, bevæger sig i to adskilte områder: produktionsområdet og reproduktionsområdet.

Grunden til og effekterne af den måde, som staten intervenerer overfor arbejderklassens situation på, kan ikke begribes gennem det materiale som AT frem-

4. Begrebet herredømmeforhold løser ikke nogle af de problemer vi har trukket frem. Det anvendes for at gøre opmærksom på hvorledes kapitalens subsumering af den private reproduktion kunne opfattes.

5. Finn Hansson har beskæftiget sig med problemet i Kurasje nr. 17 og mener, at der må skelnes mellem arbejdskraftsværdi og reproduktionsniveau, fordi de offentlige ydelser ikke er omfattet af værdiloven. Finn Hansson, Statsfunktioner og reproduktion af arbejdskraft, Kurasje nr. 17, 1978. 
lægger, men må diskuteres ud fra nogle overvejelser om, hvordan det offentlige intenderer gennem arbejdsmarkedspolitikken, social- og uddannelsespolitik at regulere arbejdernes bevægelighed på arbejdsmarkedet, øge konkurrencen mellem forskellige typer af arbejdskræfter, og dermed bidrage til ændring i reproduktionsbetingelserne og svækkelse i reproduktionskampen. Når vi taler om intentionerne i indgrebene, er det for at antyde, at den statslige krisepolitik ikke som udgangspunkt er sikret succes, og de offentlige indgreb ikke nødvendigvis kan præmieres som samfundsmæssigt funktionelle.

Vores meget almene benævnelse af forskellige politikområder - som det forekommer os vigtigt at inddrage i diskussionen - kan konkretiseres noget mere ud fra, hvad det er for nogle reproduktionsproblemer, som ændringerne i produktionsrelationerne giver anledning til i krisen. Når AT bemærker, at forudsætningen for, at staten kan tage en del af profitmassen, er, at der foregår en intensiv akkumulation med en forøgelse af udbytningsraten, så er det kun en del af sandheden. Krisen medfører ikke nødvendigvis, at den intensive akkumulation ophører eller at udbytningsraten falder, men at udbytningsraten og akkumulationen ikke stiger nok. Og det giver anledning til nedskæring i de offentlige udgifter. Men krisepolitikken kan ikke bare fortolkes som nedskæringspolitik, men må yderligere omhandle en kritik af hvordan staten søger at løse de modsætninger i reproduktionsniveauet og reproduktionskampen, som krisen giver anledning til.

Når der gennemføres en række foranstaltninger til besparelse på dagpengeområdet (børnepasningscirkulæret, efterløn, jobtilbudsordningen mv.) så skyldes det ikke bare et modsætningsforhold mellem stat og kapital fordi profitmassen til deling er blevet mindre end tidligere. Nok kan (?) statens nedskæringer skyldes at der er mindre profit til deling, men det er ikke en tilstrækkelig forklaring på hvor og hvorfor der skæres ned på bestemte felter, og dermed ikke til at forklare hvordan a) krisepolitikken influerer på reproduktionsomkostningerne eller b) krisepolitikken influerer på fordelingsforholdene imellem arbejde og kapital, fordi det afhænger af fordelingen af nedskæringen og nedskæringens konsekvenser. Altså man kan ikke betragte indtægter og udgifter så adskilte som AT gør. F.eks. må der inddrages en kritik af hvilke arbejdergrupper, der udskilles fra arbejdsmarkedet, hvilke der tvinges til at bevæge sig geografisk og hvilke der tvinges til at overskride hævdvundne faggrænser. Altså i sin helhed en kritik af statens indgreb og kontrol overfor arbejdernes bevægelighed på arbejdsmarkedet.

Niveauet i arbejdsløshedsunderstøttelsen falder ikke i samme takt som arbejdsløsheden stiger, fordi reservearmeen har en funktion til forøgelse af konkurrencen mellem arbejderne og dermed indvirker på - ikke værdien som AT mener, men - prisen af arbejdskraft. Men reservearmeen kan i omfang og 
kvalitet udvikles sådan, at den indeholder elementer, som ikke virker trykkende ind på hverken lønudviklingen eller dæmpende på reproduktionskampen. Krisepolitikkens problem ang. bidrag til de ubeskæftigede er at regulere reproduktionsomkostningerne sådan, at disse udgifter minimeres, samtidig med at den nødvendige mængde og kvalitet af arbejdskraft er til rådighed på arbejdsmarkedet.

Den statslige krisepolitik indenfor arbejdskraftsreproduktionen er altså en statslig regulering af visse arbejderes ret og mulighed for at genskabe deres vare arbejdskraft. Disse indgreb har gennem deres indflydelse på reproduktionsniveau og -kamp, differentieret mellem forskellige typer af arbejdere, nogle politiske konsekvenser, som venstrefløjen må udvikle kritik og strategi overfor. På det grundlag, som AT anvender, mener vi ikke der er mulighed for udvikling af en sådan kritik og strategi overfor den statslige krisepolitik.

\section{Hvilke momenter skal en analyse af krisepolitikken indeholde?}

Med den vigtige konstatering af, at når statens фkonomiske grundlag er den producerede (og realiserede) merværdi, forliver rammerne for den statslige krisepolitik kvantitativt bestemt af omfanget af den producerede merværdi, er nødvendigheden af at fundere diskussionen af krisepolitikkens udvikling og dens genemslagskraft $i$ en bestemmelse af krisens karakter påpeget. Men der er også påpeget, at når intentionen er at diskutere kriseindgrebenes virkninger dels på reproduktionsomkostningerne og dels på totalprofitmassens størrelse, er det som udgangspunkt sikkert rigtigt, men i analysen langt fra tilstrækkeligt alene at fastholde, at krisen er en overakkumulationskrise, at det udløsende og afg $\varnothing$ rende modsætningsforhold er forholdet mellem totalprofitmassens størrelse og den anlagte kapital.

Problemet er ifølge forfatterne, at »den anlagte kapital er vokset hurtigere end den totale profitmasse, som har betydet en faldende profitrate «. At profitraten er faldet og har været faldende i det meste af efterkrigsperioden har både forfatterne og en lang tradition indenfor realanalysen været istand til at påvise. Lige så evident det er, at krisen har sin baggrund i en faldende profitrate, lige så evident er det, at denne ikke alene er tilstrækkelig til at forklare krisens gennembrud eller dens forløb, og dermed heller ikke er tilstrækkelig til at bestemme hvilke forhold, den statslige krisepolitik skal rette sig imod endsige hvilke modsætninger en evt. krisepolitik geråder ud i.

Med forfatternes egen konstatering ${ }^{6}$ af, at den nuværende krise blot er én i en række af (overakkumulations)kriser, rejser sig spørgsmålet:

6. Jvnfr. artiklen Krisen og venstrefløjens handlemuligheder, $i$ Kurasje 21, 1979. 
Hvilke nye momenter karakteriserer denne krise? og i hvilken udstrækning adskiller disse denne krise fra tidligere?

I forhold til de mange konjunkturnedgange i den forholdsvist lange efterkrigsprosperitet peger alene længden og dybden på behovet for forklaringer, der ikke alene omfatter kvantitative, men også kvalitative forhold ved denne krise.

Med konstateringen af krisens baggrund i overakkumulation, peges tillige på, at den afgørende hindring for kapitalens ekspansion, for en opløsning af krisen, er kapitalen selv. Gennemslaget havde baggrund i, at de stoflige forudsætninger for en forøgelse af merværdiproduktionen, nemlig en forøgelse af produktivkraften, ikke kunne finde sted indenfor rammerne af den allerede producerede profit. Krisen havde baggrund i, mangel på profit, mangel på ubetalt arbejde fordi der var for lidt levende arbejde i forhold til den ophobede kapital, og ingen nok så ændret fordeling indenfor det ubetalte arbejde (det som AT kalder totalprofitmasse dvs. industriel profit+skat) kan løse op for det problem, at det eksisterende kapitalgrundlag er hindringen for den fornyede ekspansion.

Betragter man den kontekst statens beslaglæggelse af merværdi diskuteres i i artiklen, når man frem til den stik modsatte konklusion. Af det, som er hjørnestenen i artiklens argumentation, arbejdsdagens fordeling på statsbelagt-, industriel profit og disponibel arbejdsløn, fremstår det som om indskrænkningerne i den industrielle profit ikke hidrører fra den faldende udbytning, men primært fra den statslige beslaglæggelse af merværdi. Den største hindring for kapitalens uindskrænkede herredømme er således ikke kapitalen selv eller arbejderklassen, men staten via sin beslaglæggelse af merværdi. (En ting gør det vanskeligt at diskutere artiklens diskussioner, nemlig at der argumenteres i forlængelse af den tradition, der alene diskuterer fordelingen af værdiproduktet, altså løn/profitkvote, men ikke relaterer denne til profitproduktionsbetingelserne).

Den tydeligt stagnative karakter - at der hverken har været tale om et dybtgående kumulativt forfald eller er udsigt til et umiddelbart opsving - provokerer således også til spørgsmålet om hvilke stoflige nye kvaliteter satter $i$ den nuvarende krise betingelserne for henholdsvis arbejderklassens og kapitalens reproduktion - og i denne sammenhæng - hvilke momenter af irreversibel karakter må statens evt. indgreb være betinget af, eller stå i forhold til? ${ }^{7}$

Det vi plæderer for er altså langt mere en diskussion af, hvilke momenter skal drages ind i analysen for at overvinde den stagnation der i stigende grad præger også de marxistiske kriseanalyser, herunder hvilken betydning skal det tillægges, at arbejderklassens reproduktion ikke alene og jo længere tilsynela-

7. Sml. Finn Hansson og Peder Lærke Nielsen op.cit. 
dende jo mindre er formidlet over værdiformerne. Omvendt kunne man stille spørgsmålet om, hvordan vi undgår, at vanskeligheden i at følge de udviklinger op, der kommer og er kommet frem også i Kurasje, resulterer i tilbagefald til alene at diskutere abstrakt i forhold til en lukkende ramme af formale kvantitative fordelingsforhold.

\section{Hvad er resultaterne af fem års krisepolitik, eller hvem plyndrer staten?}

Som nævnt var intentionen med artiklen at unders $\varnothing$ ge dels krisepolitikkens virkninger overfor lønarbejdernes levevilkår, dels at undersøge virkningerne med hensyn til en forbedring af profitgrundlaget for en opretholdelse af muligheden for privat produktion. Altså etablering af betingelser, der kunne danne grundlaget for et $\varnothing$ konomisk genopsving. Resultatet af analysen kan kort sammenfattes således: for så vidt angår arbejderklassens levevilkår, har det aspekt, der indgår i undersøgelsen for de beskæftigede, reallønnen, været konstant eller stigende siden krisens gennembrud (se tabel 8), udbytningsgraden har været faldende til niveauet fra midten af 60'erne (tabel 8 og tabel 2) og da beskæftigelsen, som med hensyn til profitmassens størrelse er den faktor, der kan modvirke faldet $\mathrm{i}$ udbytningsraten, er faldet parallelt med denne, må den totale profitmasse være faldet endnu mere.

Var udgangspunktet for krisen således, at omfordelingen fra arbejde til kapital ikke var stor nok, var rationaliteten for en kriseløsningsstrategi, at mere arbejde skulle tilfalde kapitalen, mindre arbejderne, kan resultatet af fem års krise i følge artiklen kun siges at have gjort ondt værre: den totale arbejdsdag er blevet mindre (på grund af faldet i beskæftigelsen), en lige stor eller stфrre del heraf tilfalder arbejderen (jvnfr. faldende udbytningsgrad) og af den del, der ikke er tilfaldet arbejderen har staten beslaglagt en stadig større del (jvnfr. fig. 4).

Dermed bliver det som forudsætning for en kritisk forholden sig til krisepolitikken vigtigt at stille spørgsmålene:

Hvem er det staten plyndrer?

Er det arbejderklassen eller er det kapitalen?

Hvem er det, der plyndrer staten?

Er dét kapitalen, eller er det arbejderklassen?

Hvilke konsekvenser får dette for en socialistisk strategi? 
I artiklens figur 1 illustreres det, hvordan skatter og afgifter går fra den nominelle løn (iflg. artiklen lig med den variable kapital), således at der kun bliver reel disponibel arbejdsløn tilbage. Det vil sige at ændringer i skattetrykket sænker den variable kapitals størrelse og dermed forøger udbytningsraten.

Udbytningsraten forøges angiveligt med en sekundær udbytning, der foregår udenfor produktionsprocessen ${ }^{8}$, men som ikke desto mindre antages at indvirke på udbytningsraten, formindske den variable kapital og forøge den totale profit med en statslig profitfond.

Men denne fortolkning har flere varianter i artiklen. Det påpeges her andre steder, at indkomstskatterne »som sådan indgår ... ikke i arbejdskraftens værdi« (iøvrigt heller ikke vareskat) og videre at en forøgelse af skattetrykket »formindsker den del af merværdien, som han (kapitalisten) kan realisere som profit « (side 88). Og med følgende konklusion indledes en gennemgang af gennemsnitsarbejdslønnen indenfor industrien og af den offentlige udgifters fordeling på visse hovedposter: »De anførte sammenhænge udelukker imidlertid ikke, at statsapparatet midlertidig kan sænke og hæve udbytningsgraden.«

Forøgelsen af skattetrykket kan for en periode plyndre arbejderklassen, men - som artiklen fremhæver - er det ikke som sådan skattetrykket, der er afgørende for lønudviklingen, for prisen på arbejdskraft. Arbejderklassens reproduktionskamp er i sidste ende det afgørende for arbejdskraftsprisens bevægelse omkring værdien, og dermed det afgørende for udbytningsratens momentane udvikling.

Ændringerne i skattetrykket kan indvirke på reproduktionsbetingelserne, ikke sådan at der gennemføres vedvarende ændringer i arbejdskraftsprisen, men sådan, at der gennem skattepolitikken indføres differentieringer, så skattetrykket virker forskelligt ind på forskellige dele af arbejdskraften. Eks. kan ændringer i skattepolitikken betyde, at forskellige dele af reproduktionsomkostningerne kan fratrækkes skatten, hvorfor individuelle forhold i reproduktionsomkostningerne får betydning for størrelsen af den disponible arbejdsløn. Statens indvirkning på reproduktionsforholdene gennem interventioner via ændringer i skatteberegningerne er et vigtigt spørgsmål i den problemstilling som artiklen lægger op til at diskutere, men ikke selv fører videre.

8. AT refererer her til K. Marx Kapitalen bd. 3.3. s. 793, hvor begrebet sekundær udbytning nævnes, men godt nok i en anden forstand end her: »Endnu mere irrelevant og meningsløs er det at drage udlejning af huse etc. til individuel konsum ind i diskussionen. At arbejderklassen i denne form bliver bedraget og bliver det på en himmelråbende måde, er en indlysende kendsgerning, men den småhandlende som sælger levnedsmidler til den, gør det samme. Dette er en sekundær udbytning som forløber ved siden af den oprindelige, nemlig den som foregår umiddelbart i selve produktionsprocessen.« 
Den politiske diskussion - som artiklens overskrift kunne give anledning til - er således langt mere omfattende i sin helhed og må også omhandle, hvad staten anvender sine midler til. Krisepolitik er ikke kun et ydre element i klassekampen, men en særlig del, som formidles gennem den borgerlige stat. En af pointerne ved den borgerlige stats funktioner og ved finansieringen gennem lønskat er, at det bliver arbejderklassens samfundsmæssige funktion at fravriste de forskellige kapitaldele den lønandel, der bliver til skat. Med hensyn til hvad staten anvender sine midler til er spørgsmålene legio:

Skal venstrefløjen kæmpe for alle former for nedskæringer, fordi det forøger lønningerne, eller skal den kæmpe imod, fordi de går ud over kapitalens profit?? Eller mere konkret, skal vi gå ind for offentlig finansiering af barselsorlov og børneinstitutioner? Eller er det den anden vej rundt: skal venstrefløjen være kritisk overfor alle former for statsindgreb, ikke bare råbe på eks. børneinstitutioner, men i højere grad bekæmpe den borgerlige stats blanden sig $\mathrm{i}$ et stigende antal områder i samfundet, ikke bare på arbejdsmarkedet og i institutionerne, men også i familieliv o.s.v. Skal der i stedet diskuteres strategierne for offentlig finansiering af selvorganisering af de nævnte områder? 